\title{
Looking for Biological Protectors against Adverse Health Effects of Some Nanoparticles that Can Pollute Workplace and Ambient Air (A Summary of Authors' Experimental Results)
}

\author{
Larisa I. Privalova1, Boris A. Katsnelson ${ }^{*}$, Marina P. Sutunkova1, Ilzira A. Minigalieva1, \\ Vladimir B. Gurvich1, Oleg H. Makeyev³, Vladimir Ya. Shur' ${ }^{2}$, Irene E. Valamina ${ }^{3}$, \\ Svetlana V. Klinova1, Ekaterina V. Shishkina², Ilya V. Zubarev²
}

\begin{abstract}
${ }^{1}$ The Ekaterinburg Medical Research Center for Prophylaxis and Health Protection in Industrial Workers, Ekaterinburg, Russia ${ }^{2}$ The Institute of Natural Sciences, The Ural Federal University, Yekaterinburg, Russia

${ }^{3}$ The Ural State Medical University, Ekaterinburg, Russia

Email: ^bkaznelson@ymrc.ru
\end{abstract}

How to cite this paper: Privalova, L.I., Katsnelson, B.A., Sutunkova, M.P., Minigalieva, I.A., Gurvich, V.B., Makeyev, O.H., Shur, V.Ya., Valamina, I.E., Klinova, S.V., Shishkina, E.V. and Zubarev, I.V. (2017) Looking for Biological Protectors against Adverse Health Effects of Some Nanoparticles that Can Pollute Workplace and Ambient Air (A Summary of Authors' Experimental Results). Journal of Environmental Protection, 8, 844-866.

https://doi.org/10.4236/jep.2017.88053

Received: May 16, 2017

Accepted: July 11, 2017

Published: July 14, 2017

Copyright $\odot 2017$ by authors and Scientific Research Publishing Inc. This work is licensed under the Creative Commons Attribution-NonCommercial International License (CC BY-NC 4.0). http://creativecommons.org/licenses/by-nc/4.0/ (c) (i) \& Open Access

\begin{abstract}
Especially high health risks associated with impacts of metallic nanoparticles (Me-NPs) and their presence in the workplace and ambient air of not only the nano-industry but also of some long-existing traditional technologies make it necessary, along with keeping respective dangerous exposures as low as possible, to look for ways of increasing the organism's resistance to them. Based on theoretical premises of such beneficial interference with toxicokinetics and toxicodynamics of Me-NPs developed by our research team and on understanding general and specific key mechanisms of different Me-NPs' toxic action, we proposed several bioprotective complexes (BPCs) comprising mainly pectin, some vitamins, glutamate, glycine, $\mathrm{N}$-acetylcysteine, omega-3 PUFA, and different essential trace elements. Results of our animal experiments with different Me-NPs showed that, against the background of such BPCs' oral administration, the integral and specific toxicity of Me-NPs and even their genotoxicity can be markedly attenuated. Therefore we would recommend to further develop this vector of nano-toxicological research.
\end{abstract}

\section{Keywords}

Nanoparticles, Toxic metals, Bioptotectors

\section{Background}

Nanoparticles (NPs) of elemental metals and some metalloids, and even more so 
of their oxides are of special interest in the framework of health risk assessment and risk management problems. Along with engineered metallic NPs (Me-NPs), there usually exists a substantial nanoscale fraction of condensation aerosols generated as byproducts of many long existing and new technologies (steel and nonferrous metallurgies, arc-welding, laser metals treatment, etc) and thus polluting both workroom and ambient air in respective industries and adjacent areas. Other fractions of such aerosols are 8 usually presented mostly be submicron particles with dimensions above $100 \mathrm{~nm}$. Examples illustrating these statements are given in Figure 1 and Figure 2.

In such industries air is, as a rule, polluted by multi-component mixtures of chemically different particles of similar or dissimilar geometry. For instance, in arc-welding and alloyed steel making one usually finds different combinations of iron, chromium, nickel, manganese and silicon oxides, while in crude copper smelting and copper refining-those of copper, lead, cadmium, zinc, and arsenic oxides.

In the vast nano-toxicological literature of the last decade, studies concerned with the assessment of Me-NP toxicity are quite numerous. We can refer, for example, to several works devoted to the same Me-NPs that were the subject-matter of our own studies: silver [1]-[25], gold [26]-[38], copper and copper oxide [25] [39]-[48], nickel oxide [43] [49]-[53], manganese oxides [54] [55] [56], zink oxide [57]-[61], lead oxide [62] [63], silicon dioxide ([64]-[71], and a

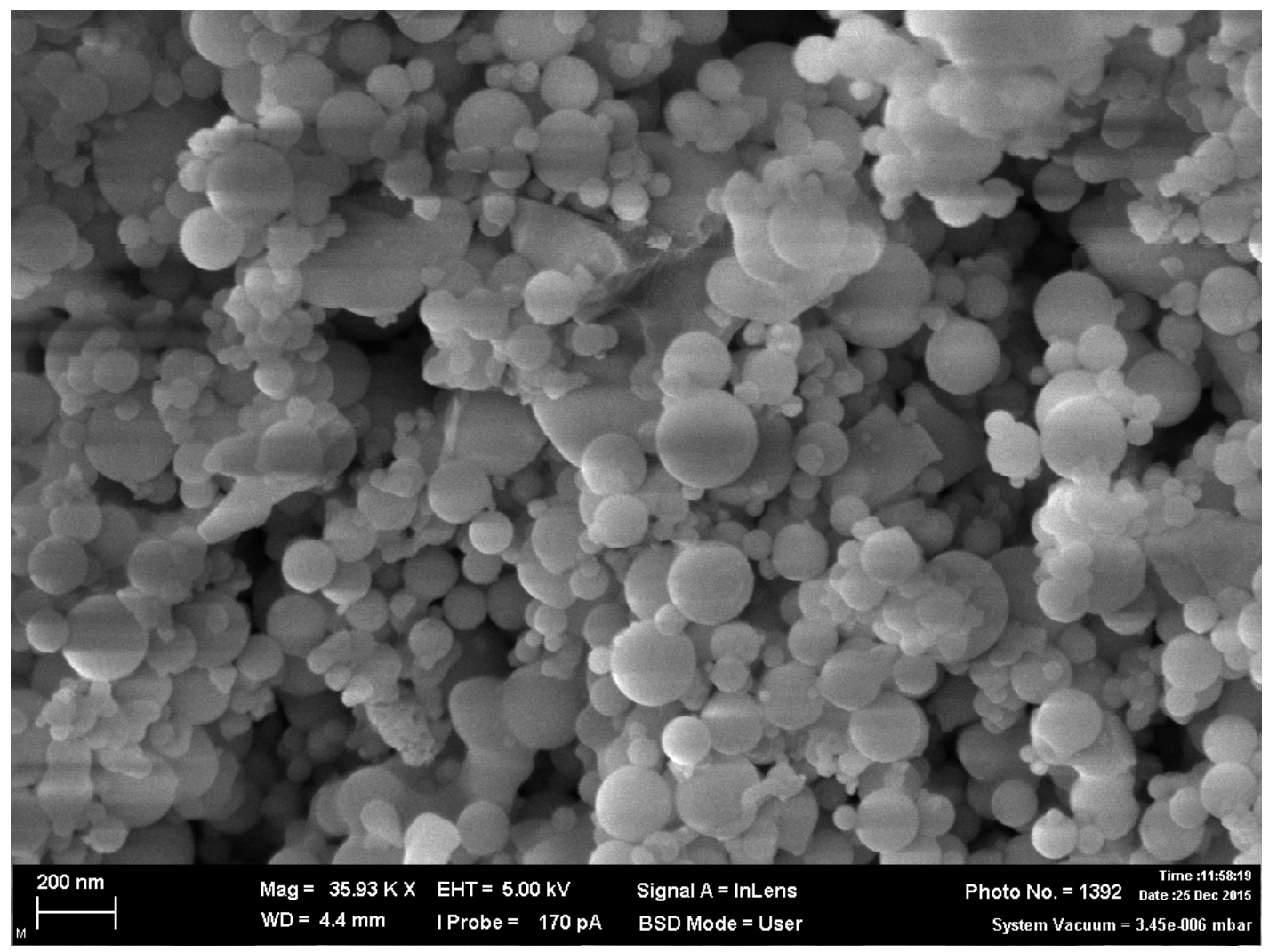

Figure 1. Particles of $\mathrm{SiO}_{2}$ collected in the flue gas duct from the hood over a silicon smelting ore-thermal furnace (scanning electron microscopy, magnification $\times 35,930$ ). 


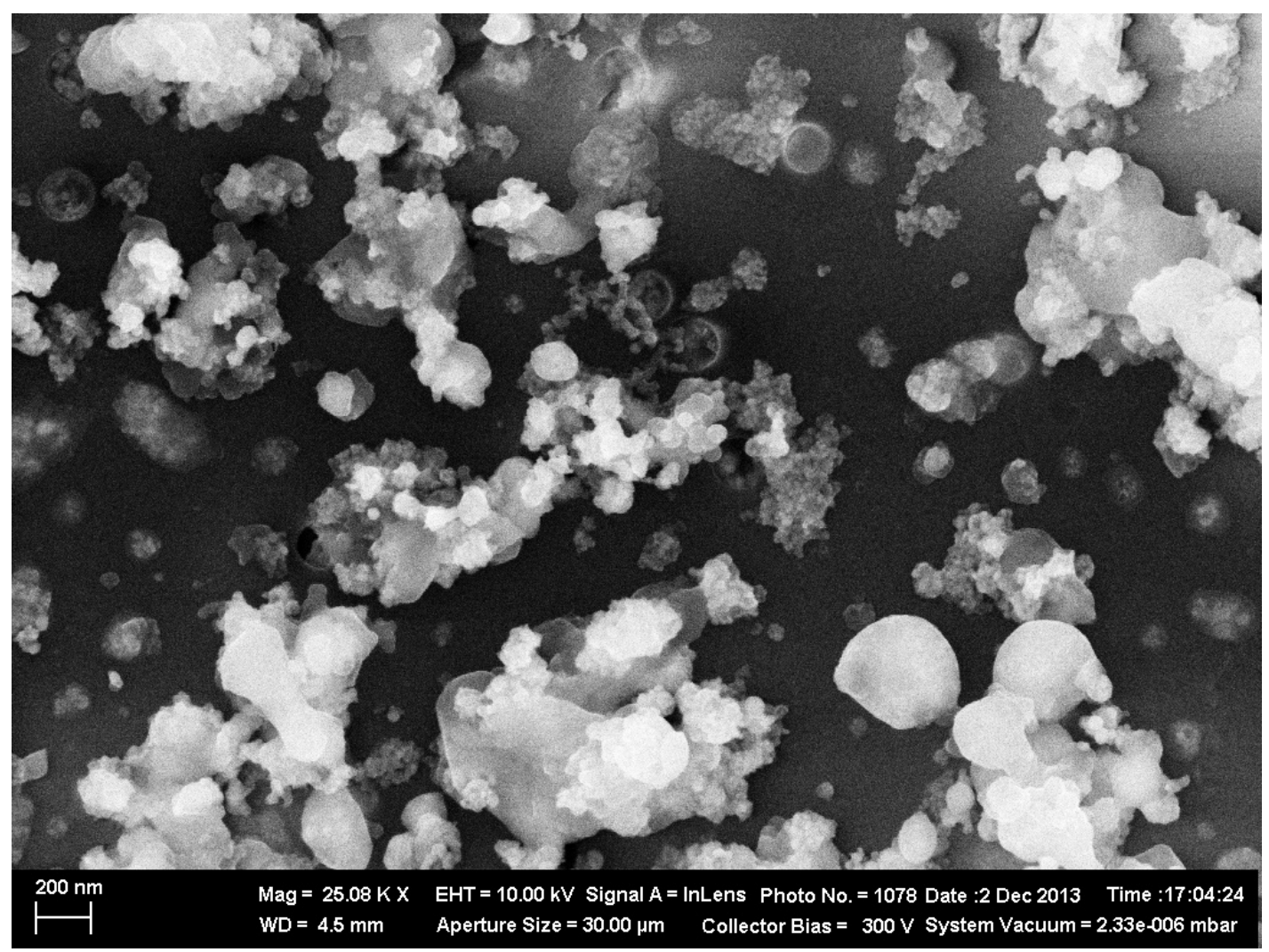

Figure 2. Particles sampled from copper smelter workplace air (SEM, magnification $\times 25,080)$.

lot of others). However, the prevailing majority of these researchers assessed adverse effects of Me-NPs in vitro on stable cell lines. This approach features a number of well-known advantages relating, in particular, to analysis of primary toxicity mechanisms on cellular and sub-cellular levels. At the same time, any extrapolation of the results of these experiments to the organism level and even the organ-systemic level is associated with a number of uncertainties and assumptions. Moreover, some important aspects (in particular, organism level toxicokinetics, relationships between doses and systemic responses, the functioning and efficiency of supracellular self-regulatory and protective mechanisms, etc.) can generally be addressed only through experiments on the whole mammalian organism. In such experiments carried out during 2010-2016 we [72]-[87] demonstrated that Mt-NPs should be considered one of the most dangerous occupational and environmental hazards due to their especially high toxicity and virtually obligatory genotoxicity.

\section{Some Theoretical Premises of Biological Protection}

Beyond any doubt, the most protectively effective way to manage occupational and environmental health risks associated with any hazardous impact would be to decrease the latter to a level exerting no observed adverse effects. However, due to the especially high toxicity and virtually obligatory genotoxicity of MeNPs, their NOAELs and respective permissible exposures to Me-NPs proposed so far are so much lower than those for chemically analogous Me-MPs (e.g. [75] 
[88] [89]) that they are hardly practicable in reality. We therefore decided to try and make the same goal attainable going from the other end, namely to enhance the natural resistance to the adverse health effects of Me-NPs [86]. This idea of possibly efficient "biological protection" against nano-toxicity was based on our long-term experience of successful bio-protection of the animal and human organism against various other toxicants, including some mineral microparticles [78] [80] [90].

The organism-level mechanisms of what we designate as bio-protection or bio-prophylaxis are schematically presented in the flow-chart (Figure 3). Although it has already been discussed by us in this Journal [80], we reckon it useful to be briefly presented here.

In general terms, we the mammalian organism can be protected against occupational or environmental toxic impacts using:

1) bio-protectors aimed primarily at increasing the effectiveness of the natural mechanisms of bio-transformation and/or elimination of toxics, and thus, at reducing the inner dose of a harmful substance retained in the organism and especially in the target organs (designated in our chart as "toxicokinetic effects");

2) bio-protectors aimed at enhancing the functional reserves at all levels of the organism affected by a toxic substance; at increasing the effectiveness of repair and compensatory processes; and at employing physiological and toxicological antagonisms (designated in the chart collectively as "toxicodynamic effects").

However, these two modes of action are usually interrelated and interdependent, as it is schematically shown with reciprocally directed arrows. Indeed, by reducing the retention of a toxic substance in the organism and especially in target organs, a bio-protector inhibits the development of a pathological process (thus, a bio-protector of a primarily toxicokinetic type of action produces a beneficial toxicodynamic effect). On the other hand, primary enhancement of resistance to the damaging impact of a toxic on the cells and organs that control the processes of its elimination or biotransformation (pulmonary macrophages, liver, kidneys) maintains the effectiveness of these processes and, thus, reduces the retention of this toxic in the organism (so we see a beneficial toxicokinetic effect of a toxicodynamic bio-protector). Such bilateral interdependence of toxicokinetic and toxicodynamic effects is pronounced to a varying degree in response to the action of different harmful substances but, on the whole, can be

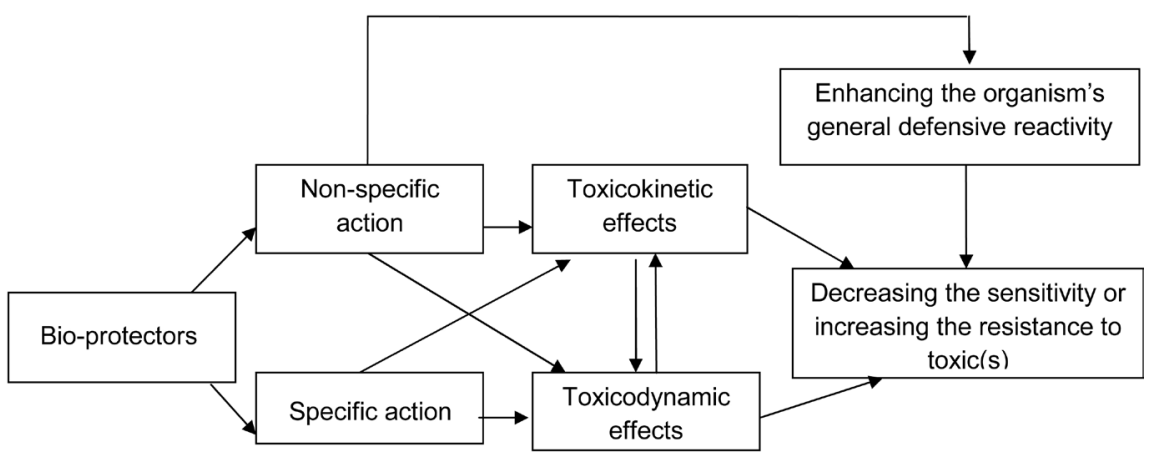

Figure 3. Schematic presentation of anti-toxic biological prophylaxis. 
considered as a consistent pattern.

The flow-chart shows also that both toxicokinetic and toxicodynamic bioprotectors can be:

- more or less specific with regard to a particular toxic or a particular range of toxics if bioprotection interferes with the mechanisms of toxicokinetics and toxicodynamics pertaining just to these toxics or to a class of similarly acting ones;

- predominantly non-specific, if their effect is realized through such integral responses at the organism level as Selye's general adaptation syndrome or a related but still distinct concept of "non-specifically enhanced resistance" developed by the school of late Nikolay Lazarev, an outstanding Russian toxicologist and pharmacologist.

However, one and the same bio-protector may, in different cases. either render a largely specific effect or help the organism mainly as an agent enhancing its nonspecific defenses and thus decreasing its sensitivity or increasing its resistance to harmful exposures (see respective boxes and links in the same chart).

In our experiments, bio-protectors employing mechanisms that are not fully identical proved to be most effective when administered in combinations which we call "bio-protective complexes", or BPCs [78] [80] [90].

As concerns bio-protection against the adverse effects of metallic nanoparticles, we have so far chosen, based on the above formulated theoretical premises, and experimentally tested four BPCs protecting from nano-silver [78], nano-copper oxide [82], and combinations of $\mathrm{NiO}-\mathrm{NP}+\mathrm{Mn}_{3} \mathrm{O}_{4}-\mathrm{NP}$ [83] [84] [85] and $\mathrm{PbO}-\mathrm{NP}+\mathrm{CuO}-\mathrm{NP}+\mathrm{ZnO}-\mathrm{NP}$ [91]. Being different in some important details depending on specific toxicodynamic and toxicokinetic mechanisms underlying the toxic action of different metals, the compositions of all those BPCs still has much in common. The most important components in all our experiments were:

1) Glutamate used by us, based on lung positive experience, as an effective cell membrane stabilizer acting through the intensification of ATP synthesis under exposure to the damaging effect of various cytotoxic particles (e.g. [92]) and, at the same time, as one of the precursors of glutathione. The latter, in its turn, serves a powerful cell protector against oxidative stress which is regarded as one of the key primary mechanisms underlying high cytotoxicity and genotoxicity of virtually all metallic NPs [93]. In addition to these non-specific and almost universal bio-protective effects of glutamate, it may more specifically increase resistance to the neurotoxicity of manganese, lead and some other Me-NPs due to its major role in the transmission of excitatory signals in the mammalian central nervous system and thus its involvement in most aspects of normal brain functioning. It is known, for instance, that manganese impairs the expression and function of the main glutamate transporters in astrocytes [94] and that lead interferes with glutamate release in the hippocampus [95]. It stands to reason that additional glutamate supply to the brain would partly compensate for these adverse effects of the respective Me-NPs.

2) The other two glutathione precursors: glycine and cysteine (the latter in a 
highly active and metabolically well available form of $\mathrm{N}$-acetylcysteine). The reasons for including these amino-acids into our BPCs were both theoretical (taking into consideration the above-mentioned general important role played by oxidative stress as a mechanism of Me-NP toxicity) and experimental as there were data of other researchers demonstrating that glutathione deficiency potentiates some specific metal toxicities-e.g. manganese-induced damage to the rat striatum and brainstem [96].

3) Other agents of the organism's anti-oxidant system: vitamins A, E, and C, and selenium (on the same theoretical grounds).

4) Omega-3 polyunsaturated fatty acids (PUFA) whose intracellular derivativeseicosanoids-activate DNA replication and thus play an important part in its repair. Meanwhile the DNA fragmentation was found to be a common effect of all Me-NPs studied by us up to now.

5) Iodine, taking into consideration the well-known disturbances of the thyroid function caused by lead, manganese and some other metallic intoxications.

6) Trace elements when they are known to be antagonists of the specific metal that form Me-NPs under study.

7) Pectin enterosorbent as an agent that hinders the re-absorption of toxic metals excreted into the intestines with bile (which, again, is of special importance for metals that are excreted predominantly by this route (e.g. manganese and copper) or released within the GIT by Me-NPs translocated there after deposition in the airways.

In all the studies we have found that, as was expected, the in vivo cyto = and organo-systemic toxicity as well as genotoxicity of Me-NPs could be noticeably attenuated against the background administration of adequately composed BPCs or by the pre-medication with them. It should be stressed that we never claimed to be the first who have shown a possibility of inhibiting some metallic nanoparticles' toxicity with the help of this or that agent targeted at a certain mechanism of such toxicity. However, other researchers would demonstrate this possibility in experiments in vitro as a rule and used it as evidence of the importance of this mechanism (e.g. [10]) rather than as the foundation of a holistic bio-protective system. In the meantime, the goal of our mechanistically substantiated approach is just such a system ("biological prophylaxis" in our terminology), and as far as we know, we were the first indeed who began to investigate the effects of bio-protectors against metallic nanoparticles in animal experiments in vivo.

\section{Examples of Results Obtained in Our Experiments}

We have demonstrated the high beneficial efficacy of anti-MeNP bioprotection in our experiments using a lot of indices, but in this self-overview we illustrate this efficacy but with some typical examples.

Thus, virtually all Me-NPs studied by us prove to be markedly nephrotoxic, causing, in particular, significant damage to the epithelial cells of proximal convoluted renal tubules. Histological preparations of kidneys in rats repeatedly exposed intraperitoneally to these nanoparticles during $6-7$ weeks revealed partial 
destruction of the brush border and marked degenerative and necrotic changes in these cells up to their disappearance, while rats exposed to the same nanoparticles against background BPC administration demonstrated absence or marked alleviation of such tubular damage. Figure 4 presents as a typical example microscopic picture of kidneys from rats exposed to a combination of NiO-NPs and $\mathrm{Mn}_{3} \mathrm{O}_{4}$-NPs with or without concomitant oral administration of a BPC comprising pectin, glutamate, glycine, $\mathrm{N}$-acetylcysteine, vitamins $\mathrm{A}, \mathrm{C}, \mathrm{E}$, selenium, iodide and omega-3 PUFA.

Table 1 provides respective morphometric results obtained in this experiment [83] and quite similar results of an earlier experiment involving copper oxide nanoparticles [81] [82] against which we tested a BPC of a similar composition plus vitamin B12 and biotic doses of iron, zinc, molybdenum and manganese.

Another well established adverse effect of virtually all Me-NPs is damage to the organs rich in RES cells, in particular, to the spleen and liver, which accumulate them more avidly than any other organs. Indeed, in both of these organs we observed an explicit pathology the type of which virtually did not depend on

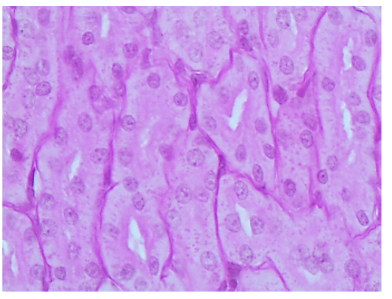

(a)

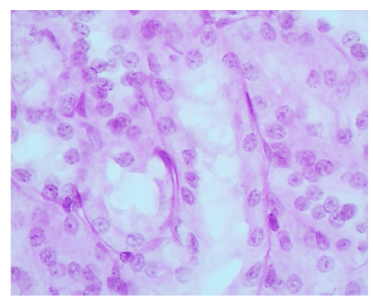

(b)

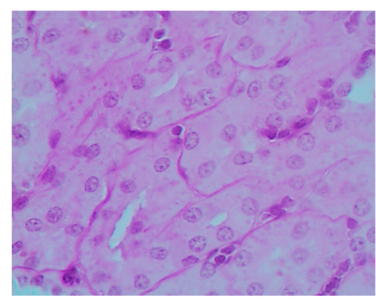

(c)

Figure 4. (a) Kidney of a control rat (proximal convoluted tubules with an intact brush border). (b) Kidney of a rat exposed to $\mathrm{NiO}-\mathrm{NPs}+\mathrm{Mn}_{3} \mathrm{O}_{4}$-NPs (marked degenerative and necrobiotic changes in tubular epithelial cells up to their disappearance; partial destruction of the brush border). (c) Kidney of a rat similarly exposed against background administration of a BPC. Periodic Acid Schiff (PAS) stain, magnification $\times 400$.

Table 1. Some morphometric indices for tubular epithelium damage in the kidneys of rats after repeated intraperitoneal injections of some metallic oxides nanoparticles with or without background oral administration of a BPC (X \pm s.e.)

\begin{tabular}{ccc}
\hline Groups of rats given & $\begin{array}{c}\text { Brush border loss } \\
\text { (\% lengthwise) }\end{array}$ & $\begin{array}{c}\text { Epithelial desquamation } \\
\text { (\% lengthwise) }\end{array}$ \\
\hline NiO nanoparticles $+\mathrm{Mn}_{3} \mathrm{O}_{4}$ nanoparticles & \\
\hline Water (control) & $5.44 \pm 0.90$ & $0.00 \pm 0.00$ \\
Nanoparticles & $12.33 \pm 2.30^{*}$ & $2.43 \pm 1.00^{*}$ \\
Nanoparticles + BPC & $7.08 \pm 1.70$ & $0.00 \pm 0.00^{+}$ \\
\hline Water (control) & $\mathrm{CuO}$ nanoparticles & $0.33 \pm 0.13$ \\
Nanoparticles & $5.39 \pm 0.42$ & $1.16 \pm 0.38^{*}$ \\
Nanoparticles + BPC & $8.36 \pm 0.76^{*}$ & $0.98 \pm 0.35$
\end{tabular}

Note: ${ }^{*}$ statistically significant difference from the control group; ${ }^{+}$from the group given nanoparticles without the BPC ( $\mathrm{p}<0.05$ by Student's t-test). 
the chemical nature of the Me-NPs, and this pathology was also alleviated by background BPCs administration as exemplified in Table 2 by the results of an experiment with Ag-NPs [78].

A more specific adverse effect characterizing the toxicity of $\mathrm{Mn}_{3} \mathrm{O}_{4}$-NPs (acting either with or without $\mathrm{NiO}-\mathrm{NPs}$ ) and $\mathrm{CuO}-\mathrm{NPs}$ was marked damage to some specialized structures of the brain (to the striatum and the hippocampus especially). In both cases, this damage was also significantly attenuated by the respective BPCs [81] [83]. Examples are given in Figure 5 and Table 3.

Table 2. Some morphometric indices of the cell structure of liver and spleen in rats exposed to Ag-NPs with or without background BPC ${ }^{1}$ administration $(x \pm$ s.e.).

\begin{tabular}{|c|c|c|c|}
\hline Index & $\begin{array}{l}\text { Rats injected } \\
\text { with water } \\
\text { (control) }\end{array}$ & $\begin{array}{l}\text { Rats injected with } \\
\text { nanoparticles }\end{array}$ & $\begin{array}{l}\text { Rats injected with } \\
\text { nanoparticles and } \\
\text { administered a BPC }\end{array}$ \\
\hline \multicolumn{4}{|c|}{ Liver } \\
\hline $\begin{array}{l}\text { Akaryotic hepatocytes } \\
\text { per } 100 \text { cells }\end{array}$ & $17.6 \pm 0.6$ & $18.5 \pm 1.3$ & $13.0 \pm 1.0^{*+}$ \\
\hline $\begin{array}{c}\text { Kupffer cells per } 100 \\
\text { liver cells }\end{array}$ & $16.5 \pm 0.5$ & $25.0 \pm 0.8^{*}$ & $20.0 \pm 0.6^{*+}$ \\
\hline $\begin{array}{l}\text { Average particle load of } \\
\text { Kupffer cells, score }\end{array}$ & 0 & $0.91 \pm 0.7$ & $0.51 \pm 0.09^{+}$ \\
\hline \multicolumn{4}{|c|}{ Spleen } \\
\hline White to red pulp ratio ${ }^{\dagger}$ & $0.59 \pm 0.036$ & $0.37 \pm 0.035^{\star}$ & $0.59 \pm 0.086^{+}$ \\
\hline
\end{tabular}

Note: ${ }^{*}$ statistically significant difference from the control group; ${ }^{+}$from the group given nanoparticles without the BPC ( $\mathrm{p}<0.05$ by Student's t-test); "the particle burden of a cell is visually estimated as a score of points from 0 to 4 . The weighted average index is calculated allowing for the percentage ratio between cells given different scores (the total number of scored cells $=100$ ); ${ }^{\dagger}$ Measured with the help of a planimetric grid.

Table 3. Some morphometric indices for the state of rat's brain after repeated intraperitoneal injections of $\mathrm{NiO}$ and $\mathrm{Mn}_{3} \mathrm{O}_{4}$ nanoparticles with or without background oral administration of a BPC $(\mathrm{X} \pm$ s.e. $)$.

\begin{tabular}{|c|c|c|c|}
\hline Golgi neurons (\%\%) & $\begin{array}{l}\text { Rats injected } \\
\text { with water } \\
\text { (control) }\end{array}$ & $\begin{array}{l}\text { Rats injected with } \\
\text { nanoparticles }\end{array}$ & $\begin{array}{l}\text { Rats injected with } \\
\text { nanoparticles and } \\
\text { administered BPC }\end{array}$ \\
\hline \multicolumn{4}{|c|}{ Nucleus caudatus } \\
\hline Without a nucleolus & $30.50 \pm 2.77$ & $60.30 \pm 2.26^{*}$ & $37.15 \pm 2.89^{+}$ \\
\hline $\begin{array}{l}\text { With a distinct centrally } \\
\text { located nucleolus }\end{array}$ & $25.12 \pm 1.16$ & $12.35 \pm 0.95^{*}$ & $23.28 \pm 1.09^{+}$ \\
\hline \multicolumn{4}{|c|}{ Hippocampus (CA 1) } \\
\hline Without a nucleolus & $30.50 \pm 2.30$ & $70.40 \pm 3.75^{\star}$ & $41.30 \pm 2.14^{\star+}$ \\
\hline $\begin{array}{l}\text { With a distinct centrally } \\
\text { located nucleolus }\end{array}$ & $46.4 \pm 2.92$ & $11.0 \pm 1.13^{*}$ & $30.5 \pm 1.96^{\star+}$ \\
\hline
\end{tabular}

Note: ${ }^{\star}$ statistically significant difference from the control group; ${ }^{+}$from the group given nanoparticles without the BPC ( $\mathrm{p}<0.05$ by Student's t-test).

${ }^{1}$ In this case, the BPC comprised pectin, glutamate, glycine, $\mathrm{N}$-acetylcysteine, vitamins A, C, E, selenium, copper, calcium and omega-3 PUFA. 


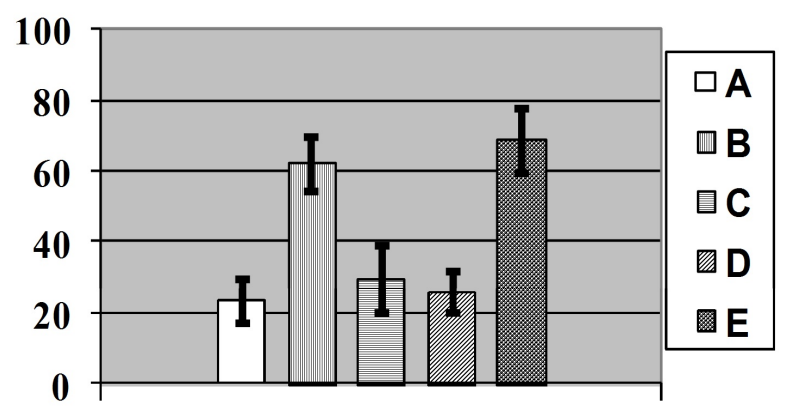

Figure 5. Number of cells without a nucleolus per 100 Golgi cells in nucleus caudatus of rats exposed (A) to water (Control); (B) to water suspension of $\mathrm{CuO}$ nanoparticles; (C) to the same against the background of bioprotective complex (BPC) administrations; (D) to the BPC only; (E) to water suspension of $\mathrm{Cu} / \mathrm{Cu}_{2} \mathrm{O}$ submicron particles (Average values with $95 \%$ $\mathrm{CI})$. Differences are statistically significant between (B) and (A), (E) and (A), and (C) and (B) ( $\mathrm{p}<0.05$ by Student's t-test).

Still another metal-specific outcome of a subchronic Me-NP intoxication was an increased reticulocytes percentage under the impact of PbO-NPs $(24.7 \%$ o \pm $2.7 \%$ against $10.2 \%$ o $\pm 1.4 \%$ in control rats, $\mathrm{P}<0.05)$. This effect was even more pronounced under a combined impact of PbO-NPs + CuO-NPs + ZnO-NPs $(29.7 \%$ o $\pm 3.2 \%$ o $)$ but was significantly attenuated $(18.00 \%$ o $\pm 1.6 \%$ o, $\mathrm{p}<0.05)$ under the same impact against background administration of a $\mathrm{BPC}^{2}$. Similar attenuation (although statistically non-significant) was observed in respect to the decrease in the hemoglobin level and to the increase in the $\delta$-ALA urine concentration [91].

To illustrate the efficacy of bioprotection against non-specific systemic toxic effects of Me-NPs, we may once again provide some results of the experiment involving nickel oxide in combination with manganese oxide nanoparticles. Table 4 presents the values of those indices for which the difference between the groups exposed to these Me-NPs with vs. without BPC administration proved statistically significant, but there were even more indices in the protected group that lost their statistically significant distinction from the control values. In general, the group exposed to the Me-NPs combination without protection had a statistically significant adverse deviation from the control value in 25 out of the 50 functional and biochemical indices for the organism's status, whereas only one index (decrease in the number of head dips into holes) was observed to have such deviation in the group so exposed along with background BPC administration [83]. This table also demonstrates that the BPC, which significantly attenuated the adverse effects caused by nanoparticles, had by itself no effect on the respective indices. This is quite typical of all our experiments.

It should also be stressed that significant attenuation in the toxic effects was not necessarily associated with a decrease in the target organ's burden of toxic

${ }^{2}$ Apple pectin, glutamate, glycine, $N$-acetylcysteine, vitamins A, C, D3, E, selenium, omega-3 rich PUFA, calcium, iodide, iron supplements 
Table 4. Some functional indices for the condition of rat after repeated intraperitoneal injections of $\mathrm{NiO}$ and $\mathrm{Mn}_{3} \mathrm{O}_{4}$ nanoparticles and/or oral administration of a $\mathrm{BPC}(\mathrm{X} \pm$ s.e.).

\begin{tabular}{ccccc}
\hline Index & Water & \multicolumn{3}{c}{ Groups given: } \\
& $\begin{array}{c}\text { Nanoparticles } \\
\text { (control) }\end{array}$ & $\begin{array}{c}\text { Nanoparticles } \\
\text { and BPC }\end{array}$ & BPC \\
$\begin{array}{c}\text { Leukocytes, } 10^{3} / \mu \mathrm{l} \\
\text { Bilirubin in blood } \\
\text { serum, } \mu \mathrm{mol} / \mathrm{L}\end{array}$ & $2.3 \pm 0.4$ & $6.1 \pm 0.5^{*}$ & $5.7 \pm 0.6^{+}$ & $4.3 \pm 0.4$ \\
$\begin{array}{c}\text { Albumin in blood } \\
\text { serum, g/L }\end{array}$ & $46.6 \pm 0.8$ & $38.6 \pm 0.8^{*}$ & $41.8 \pm 1.1^{+}$ & $47.3 \pm 1.2$ \\
$\begin{array}{c}\text { Diuresis, ml } \\
\text { Urine relative } \\
\text { density }\end{array}$ & $32.7 \pm 1.8$ & $17.9 \pm 2.9^{*}$ & $30.2 \pm 2.7^{+}$ & $31.2 \pm 4.5$ \\
$\begin{array}{c}\text { Creatinine in } \\
\text { urine, mmol/L }\end{array}$ & $1.017 \pm 0.001$ & $1.023 \pm 0.001^{*}$ & $1.019 \pm 0.001^{+}$ & $1.019 \pm 0.001$ \\
$\begin{array}{c}\delta \text {-ALA in urine, } \\
\mu m o l / d a y\end{array}$ & $0.23 \pm 0.07$ & $0.54 \pm 0.13$ & $0.22 \pm 0.02^{+}$ & $0.25 \pm 0.08$ \\
\hline
\end{tabular}

Note: ${ }^{*}$ statistically significant difference from the control group; + from the group given NiO-NPs + $\mathrm{Mn}_{3} \mathrm{O}_{4}$-NPs (without the BPC) ( $\mathrm{p}<0.05$ by Student's t-test with Bonferroni correction).

metal, although this beneficial toxicokinetic effect of the BPCs was also observed in some experiments, as illustrated by Table 5 [82]. In the experiment with a combined exposure to NiO-NPs plus $\mathrm{Mn}_{3} \mathrm{O}_{4}$-NPs [83], BPC administration significantly decreased the retention of nickel, though not of manganese, in the liver, spleen and brain. Under exposure to Ag-NPs, the retention of silver in the liver, spleen and kidneys over the control levels was very significant but did not depend at all on BPC administration [78]. We believe that this seeming inconsistency is due to the predominance of toxicodynamic bio-protection mechanisms over toxicokinetic ones.

All of the above-described results demonstrate the attenuating effects of the bioprotectors on the subchronic systemic toxicity of Me-NPs. Meanwhile, it was similarly demonstrated that the same bioprotectors also beneficially influenced the immediate pulmonary response to the deposition of NPs in the lower airways. To this end, we carried out two experiments with BPC premedication during 4 weeks before the instillation of $\mathrm{NiO}-\mathrm{NPs}+\mathrm{Mn}_{3} \mathrm{O}_{4}$-NPs [79] or PbO-NPs $+\mathrm{CuO}-\mathrm{NPs}+\mathrm{ZnO}-\mathrm{NPs}$ [97] and assessed this response by total and differential cell counts and by some biochemical BALF indices. In both experiments, as demonstrated by Table 6, we observed the usual prevalence of neutrophil leukocyte (NL) recruitment over that of alveolar macrophages (AMs), which is the most characteristic feature of the immediate pulmonary reaction to an impact of cytotoxic particles, including all Me-NPs studied by us up until now. In both experiments, the increase in the BALF NL count and NL/AM ratio over the respective control values was significantly lower in rats exposed to the same Me-NPs after a premedication with BPCs.

Taking the experiment with $\mathrm{PbO}-\mathrm{NPs}+\mathrm{CuO}-\mathrm{NPs}+\mathrm{ZnO}-\mathrm{NPs}$ as an example, 
Table 5. Copper content of some organs ( $\mathrm{mcg} / \mathrm{g}$ of dry-frozen tissue) in rats after repeated intraperitoneal injections of copper oxide nanoparticles and/or oral administration of a BPC $(x \pm$ s.e. $)$.

\begin{tabular}{ccccc}
\hline Group of rats given & Kidneys & Liver & Spleen & Brain \\
\hline Water (control) & $42.4 \pm 2.9$ & $12.2 \pm 2.4$ & $22.5 \pm 2.1$ & $18.9 \pm 0.7$ \\
CuO-NPs & $62.5 \pm 7.1^{*}$ & $28.8 \pm 6.3^{*}$ & $24.2 \pm 1.5$ & $21.5 \pm 1.7$ \\
CuO-NPs and BPC & $59.4 \pm 10.0$ & $22.1 \pm 3.5^{\star}$ & $18.0 \pm 2.5^{+}$ & $18.8 \pm 1.4$ \\
BPC & $50.4 \pm 5.6$ & $10.6 \pm 0.3$ & $25.3 \pm 2.2$ & $20.8 \pm 1.5$ \\
\hline
\end{tabular}

Note: ${ }^{*}$ statistically significant difference from the control group; ${ }^{+}$from the group given nanoparticles without the BPC ( $\mathrm{p}<0.05$ by Student's t-test).

Table 6. Influence of bioprotective premedication on the cell counts in the bronchoalveolar lavage fluid (BALF) of rats exposed to different metallic nanoparticles ( \pm \pm s.e.)

\begin{tabular}{|c|c|c|c|c|}
\hline \multirow[b]{2}{*}{ Exposure to: } & \multicolumn{3}{|c|}{ Number of cells $\times 10^{6}$} & \multirow[b]{2}{*}{$\begin{array}{c}\text { NL/AM } \\
\text { count ratio }\end{array}$} \\
\hline & total & $\begin{array}{l}\text { neutrophil } \\
\text { leukocytes } \\
(\mathrm{NL})\end{array}$ & $\begin{array}{c}\text { alveolar } \\
\text { macrophages } \\
\text { (AM) }\end{array}$ & \\
\hline \multicolumn{5}{|c|}{24 hours after the intratracheal instillation of NiO-NPs and $\mathrm{Mn}_{3} \mathrm{O}_{4}+\mathrm{NPs}$} \\
\hline Me-NPs & $9.6 \pm 1.6^{*}$ & $7.17 \pm 1.24^{*}$ & $2.3 \pm 0.43$ & $3.44 \pm 0.62^{*}$ \\
\hline $\begin{array}{l}\text { Me-NPs after } 4 \\
\text { weeks BPC } \\
\text { administration }\end{array}$ & $5.7 \pm 1.49$ & $3.36 \pm 1.38^{\star+}$ & $2.3 \pm 0.29$ & $1.46 \pm 0.54^{*+}$ \\
\hline $\begin{array}{l}\text { Water after } 4 \\
\text { weeks BPC } \\
\text { administration }\end{array}$ & $3.8 \pm 0.75$ & $0.67 \pm 0.21$ & $3.09 \pm 0.64$ & $0.23 \pm 0.07$ \\
\hline Water (control) & $3.8 \pm 0.9$ & $0.34 \pm 0.12$ & $3.4 \pm 0.86$ & $0.12 \pm 0.05$ \\
\hline \multicolumn{5}{|c|}{24 hours after the intratracheal instillation of $\mathrm{PbO}-\mathrm{NPs}+\mathrm{CuO}-\mathrm{NPs}+\mathrm{ZnO}-\mathrm{NPs}$} \\
\hline Me-NPs & $7.93 \pm 0.62^{\star}$ & $5.86 \pm 1.52^{*}$ & $2.07 \pm 0.21$ & $2.83 \pm 0.77$ \\
\hline $\begin{array}{l}\text { Me-NPs after } 4 \\
\text { weeks BPC } \\
\text { administration }\end{array}$ & $3.30 \pm 0.53^{\star+}$ & $1.47 \pm 0.36^{+*}$ & $1.82 \pm 0.40$ & $1.11 \pm 0.30^{+}$ \\
\hline $\begin{array}{c}\text { Water after } 4 \\
\text { weeks BPC } \\
\text { administration }\end{array}$ & $2.18 \pm 0.41$ & $1.20 \pm 0.35^{\star}$ & $0.98 \pm 0.25$ & $1.59 \pm 0.55^{*}$ \\
\hline Water (control) & $1.40 \pm 0.07$ & $0.094 \pm 0.029$ & $1.30 \pm 0.07$ & $0.075 \pm 0.024$ \\
\hline
\end{tabular}

Note: ${ }^{*}$ statistically significant difference from the control group; ${ }^{+}$from the group given nanoparticles without the BPC $(\mathrm{p}<0.05$ by Student's t-test).

Table 7 demonstrates that all biochemical BALF indices for AM damage (such as the release of lysosomal enzymes) or for inflammation with increased vascular permeability (increased albumin content) were also lower in rats exposed after BPC premedication. Although the intergroup difference for each index is not significant statistically, the probability of a unidirectional chance difference between the groups in all 4 indices is $<0.1(0.0625)$

In the same context of pulmonary anti-NP protection, of interest are also 
Table 7. Influence of bioprotective premedication on the biochemistry of the bronchoalveolar lavage fluid (BALF) of rats exposed i.t. to a Me-NP combination (x \pm s.e.).

\begin{tabular}{ccccc}
\hline & \multicolumn{4}{c}{ Exposure to } \\
\cline { 2 - 5 } Indices & $\begin{array}{c}\text { Water } \\
\text { (control) }\end{array}$ & Me-NPs & $\begin{array}{c}\text { Me-NPs after 4 } \\
\text { weeks BPC } \\
\text { administration }\end{array}$ & $\begin{array}{c}\text { Water after 4 } \\
\text { weeks BPC } \\
\text { administration }\end{array}$ \\
\hline Albumin, g/L & $1.90 \pm 0.08$ & $2.50 \pm 0.16^{*}$ & $2.20 \pm 0.06^{*}$ & $1.99 \pm 0.05$ \\
$\begin{array}{c}\text { Amylase, IU/L } \\
\gamma \text {-Glutamyl } \\
\text { transpeptidase, } \\
\text { IU/L }\end{array}$ & $6.56 \pm 1.20$ & $49.09 \pm 15.46^{*}$ & $27.75 \pm 7.86^{*}$ & $9.81 \pm 1.47$ \\
$\begin{array}{c}\text { Lactate } \\
\text { dehydrogenase, } \\
\text { IU/L }\end{array}$ & $54.60 \pm 10.74$ & $91.10 \pm 18.96$ & $3.64 \pm 1.10$ & $1.15 \pm 0.43$ \\
\hline
\end{tabular}

Note: *statistically significant difference from the control group ( $\mathrm{p}<0.05$ by Student's $\mathrm{t}$-test).

some data obtained by us in a chronic inhalation experiment with iron oxide nano-aerosol (Sutunkova et al., 2016). Airborne $\mathrm{Fe}_{2} \mathrm{O}_{3}$-NPs with a mean diameter of $14 \pm 4 \mathrm{~nm}$ obtained by sparking from $99.99 \%$ pure iron rods were fed during 4 months, 5 times a week, 4 hrs per day into a nose-only exposure chamber for rats, while an analogous chamber was used for sham exposures. The mean ( \pm s.e.) concentration of $\mathrm{Fe}_{2} \mathrm{O}_{3}$-NPs was equal to $1.21 \pm 0.17 \mathrm{mg} / \mathrm{m}^{3}$. When being out of the chambers, half of the animals were given to drink $1.5 \%$ sodium glutamate solution (which is an obligatory component of all our BPCs) instead of water. It had been repeatedly demonstrated that drinking this solution increased dramatically organism's resistance to the cytotoxicity, pulmonotoxicity and fibrogenicity of inhaled quartz dust and even decreased respective indices in control rats as well (e.g. [92]).

As follows from the results of this experiment (Table 8), glutamate proved to be an effective bioprotector against inhaled $\mathrm{Fe}_{2} \mathrm{O}_{3}$-NPs even if administered alone. Its protective efficacy was demonstrated in the same rats also when assessing the influence of iron oxide inhalation, with or without drinking the glutamate solution, by the activity of well known marker enzymes in the BALF. Thus, for lactate dehydrogenase activity, the average values ( $x \pm$ s.e.) were $33.80 \pm$ $2.78 \mathrm{IU}$ in control (sham exposed) rats and $43.00 \pm 7.39 \mathrm{IU}$ in those inhaling NPs, while the same inhalation exposure with glutamate drinking provided only $26.40 \pm 2.96 \mathrm{IU}(\mathrm{p}<0.05)$. For $\gamma$-glutamyl transpeptidase, the respective values were $4.08 \pm 0.28,6.09 \pm 0.87$ and $4.02 \pm 0.44 \mathrm{IU}(\mathrm{p}<0.05)$.

Along with protective action of the tested BPCs on cell and organ-systemic levels, it was demonstrated also on sub-cellular and molecular ones.

In rats exposed to repeated IP injection of CuO-NPs, PbO-NPsand/or ZnONPs [91], transmission electron microscopy of liver, spleen, kidney, myocardium, brain, thymus and testicle tissues revealed uniform ultrastructural changes, the most frequent being vacuolisation of the cytoplasm with concentric membranous inclusions in it, demyelinizations of nervous fibres in the brain and 
Table 8. Influence of glutamate solution drinking on the cell counts in the bronchoalveolar lavage fluid (BALF) of rats chronically exposed to $\mathrm{Fe}_{2} \mathrm{O}_{3}$-NPs in the inhaled air ( $\mathrm{x} \pm$ s.e.).

\begin{tabular}{ccccc}
\hline & \multicolumn{3}{c}{ Number of cells $\times 10^{6}$} & \\
\cline { 2 - 4 } Exposure & Total & $\begin{array}{c}\text { Neutrophil } \\
\text { leukocytes } \\
(\mathrm{NL})\end{array}$ & $\begin{array}{c}\text { Alveolar } \\
\text { macrophages } \\
\text { (AM) }\end{array}$ & $\begin{array}{c}\text { NL/AM } \\
\text { count ratio }\end{array}$ \\
\hline $\begin{array}{c}\text { Sham (drinking } \\
\text { water) }\end{array}$ & $2.16 \pm 0.22$ & $0.22 \pm 0.05$ & $1.93 \pm 0.19$ & $0.12 \pm 0.02$ \\
$\begin{array}{c}\text { Sham (drinking } \\
\text { glutamate) }\end{array}$ & $1.52 \pm 0.13^{*}$ & $0.11 \pm 0.02$ & $1.40 \pm 0.13$ & $0.09 \pm 0.05$ \\
$\begin{array}{c}\text { Fe } \mathrm{O}_{3} \text {-NPs } \\
(\text { drinking water) }\end{array}$ & $1.96 \pm 0.18$ & $0.43 \pm 0.07^{*}$ & $1.51 \pm 0.18$ & $0.32 \pm 0.07^{*}$ \\
$\begin{array}{c}\mathrm{Fe}_{2} \mathrm{O}_{3} \text {-NPs (drinking } \\
\text { glutamate) }\end{array}$ & $1.76 \pm 1.53$ & $0.24 \pm 0.04^{+}$ & $1.52 \pm 0.09$ & $0.15 \pm 0.02^{+}$ \\
\hline
\end{tabular}

Note: * ${ }^{\star}$ statistically significant difference from the control group; ${ }^{+}$from the group inhaling nanoparticles without the glutamate drink ( $\mathrm{p}<0.05$ by Student's t-test).

especially damage to mitochondria with partial or complete loss of cristae (Figure 6 and Figure 7).

Using the percentage of damaged mitochondria as a semi-quantitative measure of this effect, we introduced the following scale: $0-0 \%, 1-$ to $30 \%, 2-$ over $30 \%$ to $70 \%$, 3-over $70 \%$. Considering not only the morpho-functional similarity of mitochondria in different cells of a given animal organism but also the repeatability of damage to the organelles in all organs and in all groups, it seemed admissible to sum up the scores across a given exposure group irrespective of organ. In this way, the mitochondrial toxicity of the triple NP combination $(\mathrm{CuO}-\mathrm{NP}+\mathrm{PbO}-\mathrm{NP}+\mathrm{ZnO}-\mathrm{NP})$ was assessed by 14 points, while the same combination against background BPC administration gave a minimal total score of 6 , whereas in the control group it was equal to 2 , all the differences being statistically significant $(\mathrm{p}<0.05$ by the Friedman rank test and the Kruskal-Wallis test).

One of the most important effects of subchronic exposures to the studied Me-NPs on the molecular level was the DNA fragmentation. All the BPCs tested by us up till now significantly attenuated this most adverse effect. An example pertaining to the experiment with Ag-NP [78] is given by Table 9.

\section{Conclusions}

Highly adverse effects of metallic nanoparticles on all levels from molecular to organ-systemic can be markedly attenuated by background administration of or premedication by adequately composed combinations of some bioactive agents in innocuous doses. We therefore believe that, along with decreasing exposures to nanoparticles, enhancing the organism's resistance to their adverse effects with the help of such bio-protectors can be an efficient auxiliary tool of health risk management. 


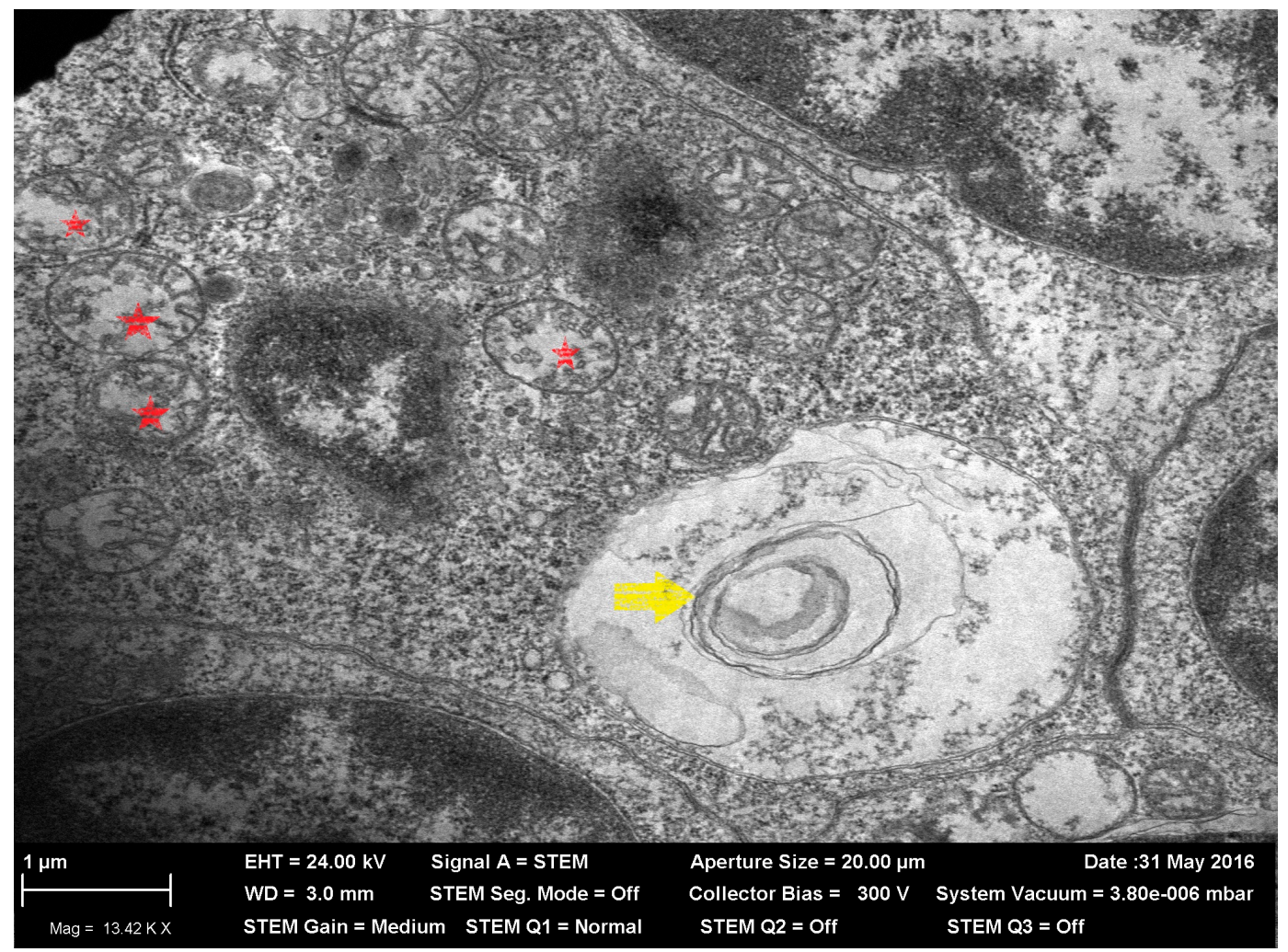

Figure 6. Concentric membranous formation and cytoplasmic vacuolization (arrow), and marked damage to mytochondria (asterisks) in a spleen cell from a rat exposed to ZnO-NPs. TEM, magnification $\times 13,420$.

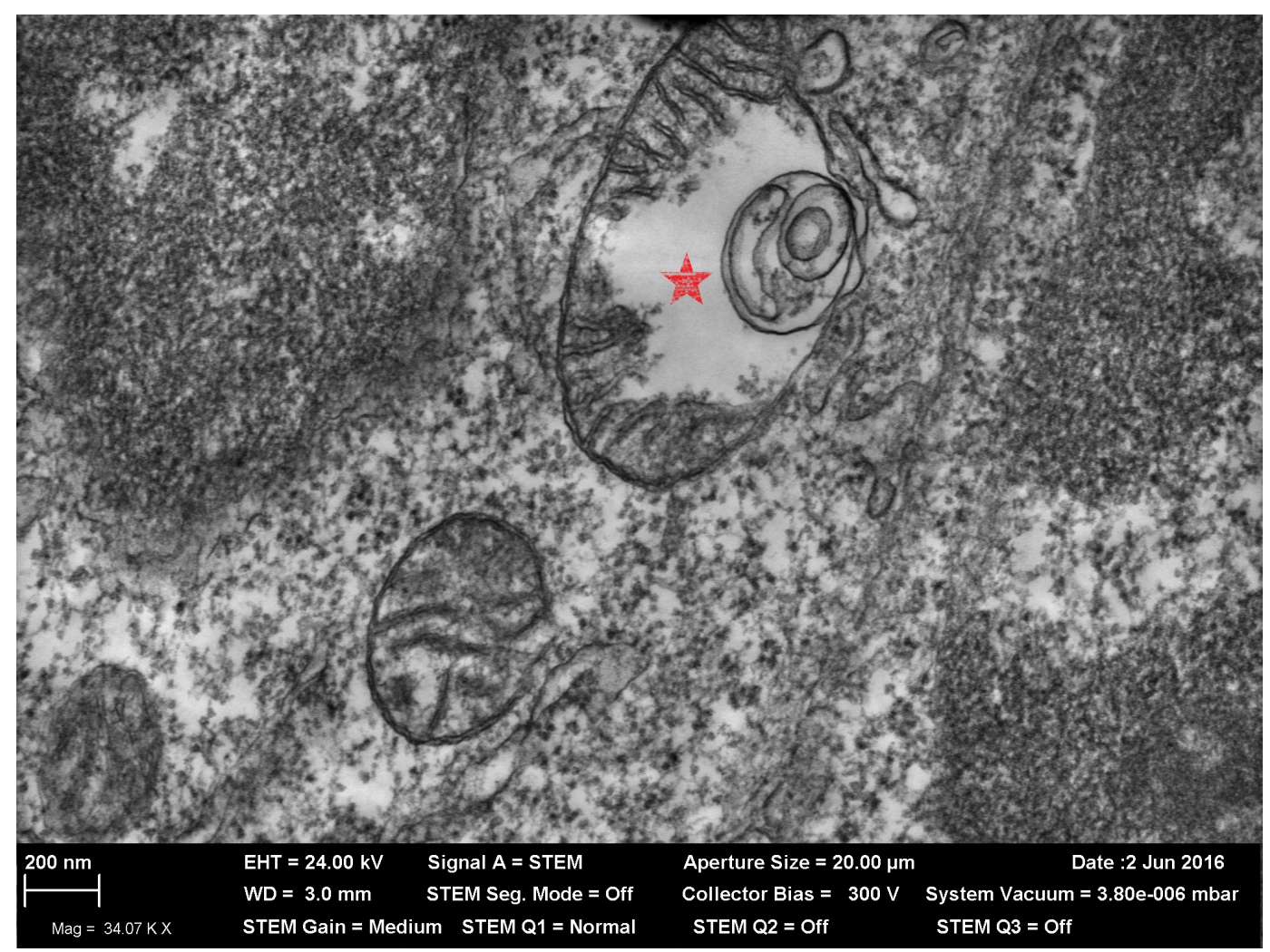

Figure 7. A partially destroyed mitochondrion (marked by asterisk) in a thymus cell of a rat exposed to $\mathrm{PbO}-\mathrm{NPs}$ and $\mathrm{ZnO}-\mathrm{NPs}$. TEM, magnification $\times 34,070$. 
Table 9. Coefficients of the genomic DNA fragmentation in rats exposed to subchronic administration of silver nanoparticles with or without BPC based on the results of RAPD test $(\mathrm{X} \pm$ s.e $)$.

\begin{tabular}{cccccc}
\hline & \multicolumn{5}{c}{ Tissues } \\
\cline { 2 - 6 } Group of given: & Liver & $\begin{array}{c}\text { Bone } \\
\text { marrow }\end{array}$ & Spleen & Kidney & $\begin{array}{c}\text { Nucleated } \\
\text { cells of blood }\end{array}$ \\
\hline Water (controls) & $0.40 \pm 0.001$ & $0.39 \pm 0.003$ & $0.38 \pm 0.002$ & $0.39 \pm 0.003$ & $0.38 \pm 0.001$ \\
Nano-particles & $0.46 \pm 0.002^{*}$ & $0.46 \pm 0.032^{*}$ & $0.46 \pm 0.001^{*}$ & $0.42 \pm 0.008^{*}$ & $0.41 \pm 0.012^{*}$ \\
$\begin{array}{c}\text { Nanoparticles } \\
\text { and BPC }\end{array}$ & $0.41 \pm 0.011^{+}$ & $0.37 \pm 0.003^{*+}$ & $0.42 \pm 0.003^{*+}$ & $0.40 \pm 0.006^{*+}$ & $0.39 \pm 0.007$ \\
\hline
\end{tabular}

Note: ${ }^{*}$ statistically significant difference from the control group; ${ }^{+}$from the group given nanoparticles without the BPC ( $\mathrm{p}<0.05$ by Student's t-test.

Our previous positive experience in organizing first a selective and then a large-scale "biological prophylaxis" of adverse health effects of many other toxicants makes us expect that it would be no less practicable and effective in the field of nanotoxicology as well.

\section{References}

[1] Ahamed, M., Karns, M., Goodson, M., Rowe, J., Hussain, S.M., Schlager, J.J. and Hong, Y. (2008) DNA Damage Response to Different Surface Chemistry of Silver Nanoparticles in Mammalian Cells. Toxicology and Applied Pharmacology, 233, 404-410.

[2] Arora, S., Jain, J., Rajwade, J.M. and Paknikar, K.M. (2009) Interactions of Silver Nanoparticles with Primary Mouse Fibroblasts and Liver Cells. Toxicology and Applied Pharmacology, 236, 310-318.

[3] Ahamed, M., AlSalhi, M.S. and Siddiqui, M.K.J. (2010) Silver Nanoparticles Applications and Human Health. Clinica Chimica Acta, 411, 1841-1184.

[4] Choi, J.E., Kim, S., Ahn, J.H., Youn, P., Kang, J.S., Park, K., Yi, J. and Ryu, D.Y. (2010) Induction of Oxidative Stress and Apoptosis by Silver Nanoparticles in the Liver of Adult Zebrafish. Aquatic Toxicology, 100, 151-159.

[5] Kim, Y.S., Song, M.Y., Park, J.D., Song, K.S., Ryu, H.R., Chung, Y.H., Chang, H.K., Lee, J.H., Oh, K.H., Kelman, B.J., Hwang, I.K. and Yu, I.J. (2010) Subchronic Oral Toxicity of Silver Nanoparticles. Particle and Fibre Toxicology, 7, 20-31. https://doi.org/10.1186/1743-8977-7-20

[6] Li, T., Albee, B., Alemayehu, M., Diaz, R., Ingham, L., Kamal, S., Rodriguez, M. and Bishnoi, S.W. (2010) Comparative Toxicity Study of Ag, Au, Ag-Au Bimetallic Nanoparticles on Daphnia Magna. Analytical and Bioanalytical Chemistry, 398, 689700. https://doi.org/10.1007/s00216-010-3915-1

[7] Park, E.-J., Bae, E., Yi, Y., Kim, Y., Choi, K., Lee, S.H., Yoon, J., Lee, B.C. and Park, K. (2010) Repeated-Dose Toxicity and Inflammatory Responses in Mice by Oral Administration of Silver Nano-Particles. Environmental Toxicology and Pharmacology, 30, 162-168. https://doi.org/10.1016/j.etap.2010.05.004

[8] Trickler, W.J., Lantz, S.M., Murdock, R.C., Schrand, A.M., Robinson, B.L., Newport, G.D., Schlager, J.J., Oldenburg, S.J., Paule, M.G., Slikker Jr., W., Hussain, S.M. and Ali, S.F. (2010) Silver Nanoparticle Induced Blood-Brain Barrier Inflammation and Increased Permeability in Primary Rat Brain Micro Vessel Endothelial Cells. Toxicological Sciences, 118, 160-170. https://doi.org/10.1093/toxsci/kfq244 
[9] Ahmadi, F. and Kordestany, A.H. (2011) Investigation on Silver Retention in Different Organs and Oxidative Stress Enzymes in Male Broiler Fed Diet Supplemented with Powder of Nano Silver. Research Journal of Pharmacology and Pharmacodynamics, 3, 28-35.

[10] Foldbjerg, R., Dang, D.A. and Autrup, H. (2011) Cytotoxicity and Genotoxicity of Silver Nanoparticles in the Human Lung Cancer Cell Line, A549. Archives of Toxicology, 85, 743-750. https://doi.org/10.1007/s00204-010-0545-5

[11] Hackenberg, S., Scherzed, A., Kessler, M., Hummel, S., Technau, A., Froelich, K., Ginzkey, C., Koehler, C., Hagen, R. and Kleinsasser, N. (2011) Silver Nanoparticles: Evaluation of DNA Damage, Toxicity and Functional Impairment in Human Mesenchymal Stem Cell. Toxicology Letters, 201, 27-33.

[12] Kim, H.R., Kim, M.J., Lee, S.Y., Oh, S.M. and Chung, K.H. (2011) Genotoxic Effects of Silver Nanoparticles Stimulated by Oxidative Stress in Human Normal Bronchial Epithelial (BEAS-2B) Cells. Mutation Research, 726, 129-135.

[13] Park, M.V., Neigh, A.M., Vermeulen, J.P., de la Fonteyne, L.J., Verharen, H.W., Briedé, J.J., van Loveren, H. and de Jong, W.H. (2011) The Effect of Particle Size on the Cytotoxicity, Inflammation, Developmental Toxicity and Genotoxicity of Silver Nanoparticles. Biomaterials, 32, 9810-9817. https://doi.org/10.1016/j.biomaterials.2011.08.085

[14] Singh, S., D’Britto, V., Prabhune, A.A., Ramana, C.V., Dhawan, A. and Prasad, B.L.V. (2011) Cytotoxic and Genotoxic Assessment of Glycolipid-Reduced and -Capped Gold and Silver Nanoparticles. New Journal of Chemistry, 34, 294-301. https://doi.org/10.1039/B9NJ00277D

[15] Srivastava, M., Singh, S. and Self, W.T. (2011) Exposure to Silver Nanoparticles Inhibits Selenoprotein Synthesis and the Activity of Thioredoxin Reductase. Environmental Health Perspectives, 120, 56-61. https://doi.org/10.1289/ehp.1103928

[16] Stebounova, L.V., Adamcakova-Dodd, A. and Kim, J.S. (2011) Nanosilver Induces Minimal Lung Toxicity or Inflammation in a Subacute Murine Inhalation Model. Particle and Fibre Toxicology, 8, 5-17. https://doi.org/10.1186/1743-8977-8-5

[17] Asare, N., Instanes, C., Sandberg, W.J., Refsnes, M., Schwarze, P., Kruszewski, M. and Brunborg, G. (2012) Citotoxic and Genotoxic Effects of Silver Nanoparticles in Testicular Cell. Toxicology, 291, 65-72. https://doi.org/10.1016/j.tox.2011.10.022

[18] Flower, N.A.L., Brabu, B., Revathy, M., Gopalakrishnan, C., Raja, S.V., Murugan, S.S. and Kumaravel, T.S. (2012) Characterization of Synthesized Silver Nanoparticles and Assessment of Its Genotoxicity Potentials Using the Alkaline Comet Assay. Mutation Research, 742, 61-65.

[19] Karlsson, H.L., Gliga, A.R., Kohonen, P., Wallberg, A. and Fadeel, B. (2012) Genotoxic and Epigenetic Effects of Silver Nanoparticles. Toxicology Letters, 211, S40.

[20] Li, Y., Chen, D.H., Yan, J., Chen, Y., Mittelstaedt, R.A., Zhang, Y., Biris, A.S., Heflich, R.H. and Chen, T. (2012) Genotoxicity of Silver Nanoparticles Evaluated Using the Ames Test and in Vitro Micronucleus Assay. Mutation Research, 745, 4-10.

[21] Lim, D.-H., Jang, J., Kim, S., Kang, T., Lee, K. and Choi, I.H. (2012) The Effects of Sub-Lethal Concentrations of Silver Nanoparticles on Inflammatory and Stress in Human Macrophages Using cDNA Microarray Analysis. Biomaterials, 33, 46904699. https://doi.org/10.1016/j.biomaterials.2012.03.006

[22] Tavares, P., Balbino, F., de Oliveira, H.M., Fagundes, G.E., Venâncio, M., Ronconi, J.V.V., Merlini, A., Streck, E.L., da Silva Paula, M.M. and de Andrade V.M. (2012) Evaluation of Genotoxic Effect of Silver Nanoparticles (Ag-NPs) in Vitro and in Vivo. Journal of Nanoparticle Research, 14, 791. https://doi.org/10.1007/s11051-012-0791-y 
[23] Beer, C., Foldbjerg, R., Hayashi, Y., Sutherland, D.S. and Autrup, H. (2012) Toxicity of Silver Nanoparticles-Nanoparticle or Silver Ion? Toxicology Letters, 208, 286292.

[24] Cronholm, P., Karlsson, H.L., Hedberg, J., Lowe, T.A., Winnberg, L., Elihn, K., Wallinder, I.O. and Möller, L. (2013) Intracellular Uptake and Toxicity of Ag and CuO Nanoparticles: A Comparison between Nanoparticles and Their Corresponding Metal Ions. Small, 9, 970-982. https://doi.org/10.1002/smll.201201069

[25] Gomes, T., Araújo, O., Pereira, R., Almeida, A.C., Cravo, A. and Bebianno, M.J. (2013) Genotoxicity of Copper Oxide and Silver Nanoparticles in the Mussel MytiIus galloprovincialis. Marine Environmental Research, 84, 51-59.

[26] Bakri, S.J., Pulido, J.S., Mukerjee, P., Marler, R.J. and Mukhopadhyay, D. (2008) Absence of Histologic Retinal Toxicity of Intravitreal Nanogold in a Rabbit Model. Retina, 28, 147-149. https://doi.org/10.1097/iae.0b013e3180dc9360

[27] Chen, Y.-Sh., Hung, Y.-Ch. and Huang, G.S. (2009) Assessment of the in Vivo Toxicity of Gold Nanoparticles. Nanoscale Research Letters, 4, 858-864. https://doi.org/10.1007/s11671-009-9334-6

[28] Pan, Y., Leifert, A., Ruau, D., Neuss, S., Bornemann, J., Schmid, G., Brandau, W., Simon, U. and Jahnen-Dechent, W. (2009) Gold Nanoparticles of Diameter $1.4 \mathrm{~nm}$ Trigger Necrosis by Oxidative Stress and Mitochondrial Damage. Small, 5, 20672076. https://doi.org/10.1002/smll.200900466

[29] Balasurbamanian, S.K., Jittiwat, J., Manikandan, J., Ong, C.N., Yu, L.E. and Ong, W.Y. (2010) Biodistribution of Gold Nanoparticles and Gene Expression Changes in the Liver and Spleen after Intravenous Administration in Rats. Biomaterials, 31, 2034-2042. https://doi.org/10.1016/j.biomaterials.2009.11.079

[30] Zhang, Q., Hitchins, V.M., Schrand, A.M., Hussain, S.M. and Goering, P.L. (2010) Uptake of Gold Nanoparticles in Murine Macrophage Cells without Cytotoxicity or Production of Proinflammatory Mediators. Nanotoxicology, 5, 284-295. https://doi.org/10.3109/17435390.2010.512401

[31] Glazer, E.S., Zhu, C., Hamir, A.N., Borne, A., Thompson, C.S. and Curley, S.A. (2011) Biodistribution and Acute Toxicity of Naked Gold Nanoparticles in a Rabbit Hepatic Tumor Model. Nanotoxicology, 5, 459-468.

https://doi.org/10.3109/17435390.2010.516026

[32] Li, J.J., Lo, S.L., Ng, C.T., Gurung, R.L., Hartono, D., Hande, M.P., Ong, C.N., Bay, B.H. and Yung, L.Y. (2011) Genomic Instability of Gold Nanoparticle Treated Human Lung Fibroblast Cells. Biomaterials, 32, 5515-5523.

https://doi.org/10.1016/j.biomaterials.2011.04.023

[33] Mustafa, T., Watanabe, F., Monroe, W., Mahmood, M., Xu, Y., Saeed, L.M., Karmakar, A., Casciano, D., Ali, S. and Biris, A.S. (2011) Impact of Gold Nanoparticle Concentration on Their Cellular Uptake by MC3T3-E1 Mouse Osteoblastic Cells as Analyzed by Transmission Electron Microscopy. Journal of Nanomedicine \& Nanotechnology, 2, 118.

[34] Trickler, W.J., Lantz, S.M., Murdock, R.C., Schrand, A.M., Robinson, B.L., Newport, G.D., Schlager, J.J., Oldenburg, S.J., Paule, M.G., Slikker Jr., W., Hussain, S.M. and Ali, S.F. (2011) Brain Microvessel Endothelial Cells Responses to Gold Nanoparticles: In Vitro Pro-Inflammatory Mediators and Permeability. Nanotoxicology, 5, 479-492. https://doi.org/10.3109/17435390.2010.540356

[35] Choi, S.Y., Jeong, S., Jang, S.H., Park, J., Park, J.H., Ock, K.S., Lee, S.Y. and Joo, S.W. (2012) In Vitro Toxicity Protein-Adsorbed Citrate-Reduced Gold Nanoparticles in Human Lung Adenocarcinoma Cells. Toxicology in Vitro, 26, 229-237. 
[36] Dykman, L. and Khlebtsov, N. (2012) Gold Nanoparticles in Biomedical Applications: Recent Advances and Perspectives. Chemical Society Reviews, 41, 2256-2282. https://doi.org/10.1039/C1CS15166E

[37] Rudolf, R., Friedrich, B., Stopic, S., Anzel, I., Tomic, S. and Colic, M. (2012) Cytotoxicity of Gold Nanoparticles Prepared by Ultrasonic Spray Pyrolysis. Journal of Biomaterials Applications, 26, 595-612. https://doi.org/10.1177/0885328210377536

[38] Shulz, M., Ma-Hock, L., Brill, S., Strauss, V., Treumann, S., Gröters, S., van Ravenzwaay, B. and Landsiedel, R. (2012) Investigation on the Genotoxicity of Different Sizes of Gold Nanoparticles Administered to the Lungs of Rats. Mutation Research, 745, 51-57.

[39] Chen, Z., Meng, H., Xing, G., Chen, C., Zhao, Y., Jia, G., Wang, T., Yuan, H., Ye, C., Zhao, F., Chai, Z., Zhu, C., Fang, X., Ma, B. and Wan, L. (2006) Acute Toxicological Effects of Copper Nanoparticles in Vivo. Toxicology Letters, 25, 109-120.

[40] Karlsson, H., Cronholm, P., Gustafsson, J. and Moller, L. (2008) Copper Oxide Nanoparticles Are Highly Toxic A Comparison between Metal Oxide Nanoparticles and Carbon Nanotubes. Chemical Research in Toxicology, 21, 1726-1732. https://doi.org/10.1021/tx800064j

[41] Studer, A.M., Limbach, L.K., Van Duc, L., Krumeich, F., Athanassiou, E.K., Gerber, L.C., Moch, H. and Stark, W.J. (2010) Nanoparticle Cytotoxicity Depends on Intracellular Solubility: Comparison of Stabilized Copper Metal and Degradable Copper Oxide Nanoparticles. Toxicology Letters, 197, 169-174.

[42] Bondarenko, O., Ivask, A., Käkinen, A. and Kahru, A. (2012) Sub-Toxic Effects of $\mathrm{CuO}$ Nanoparticles on Bacteria: Kinetics, Role of $\mathrm{Cu}$ Ions and Possible Mechanisms of Action. Environmental Pollution, 169, 81-89.

[43] Magaye, R., Zhao, J., Bowman, L. and Ding, M. (2012) Genotoxicity and Carcinogenicity of Cobalt-, Nickel- and Copper-Based Nanoparticles. Experimental and Therapeutic Medicine, 4, 551-561.

[44] Pang, C., Selck, H., Misra, S.K., Berhanu, D., Dybowska, A., Valsami-Jones, E. and Forbes, V.E. (2012) Effects of Sediment-Associated Copper to the Deposit-Feeding Snail, Potamopyrgus antipodarum: A Comparison of $\mathrm{Cu}$ Added in Aqueous Form or as Nano- and Micro-CuO Particles. Aquatic Toxicology, 106-107, 114-122.

[45] Akhtar, M.J., Kumar, S., Alhadlaq, H.A., Alrokayan, S.A., Abu-Salah, K.M. and Ahamed, M. (2016) Dose-Dependent Genotoxicity of Copper Oxide Nanoparticles Stimulated by Reactive Oxygen Species in Human Lung Epithelial Cells. Toxicology and Industrial Health, 32, 809-821. https://doi.org/10.1177/0748233713511512

[46] Alarifi, S., Ali, D., Verma, A., Alakhtani, S. and Ali, B.A. (2013) Cytotoxicity and Genotoxicity of Copper Oxide Nanoparticles in Human Skin Keratinocytes Cells. International Journal of Toxicology, 32, 296-307.

https://doi.org/10.1177/1091581813487563

[47] Cuillel, M., Chevallet, M., Charbonnier, P., Fauquant, C., Pignot-Paintrand, I., Arnaud, J., Cassio, D., Michaud-Soret, I. and Mintz, E. (2014) Interference of CuO Nanoparticles with Metal Homeostasis in Hepatocytes under Sub-Toxic Conditions. Nanoscale, 16, 1707-1715. https://doi.org/10.1039/C3NR05041F

[48] Xu, J., Li, Z., Xu, P., Xiao, L. and Yang, Z. (2013) Nanosized Copper Oxide Induces Apoptosis through Oxidative Stress in Podocytes. Archives of Toxicology, 87, 10671073. https://doi.org/10.1007/s00204-012-0925-0

[49] Zhang, Q., Yukinori, K., Sato, K., Nakakuki, K., Kohyama, N. and Donaldson, K. (1998) Differences in the Extent of Inflammation Caused by Intratracheal Exposure to Three Ultrafine Metals: Role of Free Radicals. Journal of Toxicology and Environmental Health, Part A, 53, 423-438. https://doi.org/10.1080/009841098159169 
[50] Morimoto, Y., Hirohashi, M., Ogami, A., Oyabu, T., Myojo, T., Hashiba, M., Mizuguchi, Y., Kambara, T., Lee, B.W., Kuroda, E. and Tanaka, I. (2011) Pulmonary Toxicity Following an Intratracheal Instillation of Nickel Oxide Nanoparticle Agglomerates. Journal of Occupational Health, 53, 293-295. https://doi.org/10.1539/joh.11-0034-BR

[51] Magaye, R. and Zhao, J. (2012) Recent Progress in Studies of Metallic Nickel and Nickel-Based Nanoparticles' Genotoxicity and Carcinogenicity. Environmental Toxicology and Pharmacology, 34, 644-650. https://doi.org/10.1016/j.etap.2012.08.012

[52] Capasso, L., Camatini, M. and Gualtieri, M. (2014) Nickel Oxide Nanoparticles Induce Inflammation and Genotoxic Effect in Lung Epithelial Cells. Toxicology Letters, 226, 28-34.

[53] Pang, H., Zhang, B., Du, J., Chen, J., Zhanga, J. and Lia S. (2012) Porous Nickel Oxide Nanospindles with Huge Specific Capacitance and Long-Life Cycle. RSC Advances, 2, 2257-2261. https://doi.org/10.1039/c2ra00949h

[54] Hussain, S.M., Javorina, A.K., Schrand, A.M., Duhart, H.M., Ali, S.F. and Schlager, J.J. (2006) The Interaction of Manganese Nanoparticles with PC-12 Cells Induces Dopamine Depletion. Toxicological Sciences, 92, 456-463. https://doi.org/10.1093/toxsci/kfl020

[55] Singh, S.P., Kumari, M., Kumari, S.I., Rahman, M.F., Mahboob, M. and Grover, P. (2013) Toxicity Assessment of Manganese Oxide Micro and Nanoparticles in Wistar Rats after 28 Days of Repeated Oral Exposure. Journal of Applied Toxicology, 33, 1165-1179. https://doi.org/10.1002/jat.2887

[56] Bellusci, M., La Barbera, A., Padella, F., Mancuso, M., Pasquo, A., Grollino, M.G., Leter, G., Nardi, E., Cremisini, C., Giardullo, P. and Pacchierotti, F. (2014) Biodistribution and Acute Toxicity of a Nanofluid Containing Manganese Iron Oxide Nanoparticles Produced by a Mechanochemical Process. International Journal of Nanomedicine, 9, 1919-1929.

[57] Wang, B., Feng, W.-Y., Wang, T.-C., Jia, G., Wang, M., Shi, J.W., Zhang, F., Zhao, Y.L. and Chai, Z.F. (2006) Acute Toxicity of Nano- and Micro-Scale Zinc Powder in Healthy Adult Mice. Toxicology Letters, 161, 115-123.

[58] Cho, W.-S., Duffin, R., Howie, S., Scotton, C.J., Wallace, W.A., Macnee, W., Bradley, M., Megson, I.L. and Donaldson, K. (2011) Progressive Severe Lung Injury by Zinc Oxide Nanoparticles; the Role of $\mathrm{Zn}^{2+}$ Dissolution Inside Lysosomes. Particle and Fibre Toxicology, 8, 27-43. https://doi.org/10.1186/1743-8977-8-27

[59] Adamcakova-Dodd, A., Stebounova, L.V., Kim, J.S., Vorrink, S.U., Ault, A.P., O’Shaughnessy, P.T., Grassian, V.H. and Thorne, P.S. (2014) Toxicity Assessment of Zinc Oxide Nanoparticles Using Sub-Acute and Sub-Chronic Murine Inhalation Models. Particle and Fibre Toxicology, 11, 15-30. https://doi.org/10.1186/1743-8977-11-15

[60] Jacobsen, N.R., Stoeger, T., van den Brule, S., Saber, A.T., Beyerle, A., Vietti, G., Mortensen, A., Szarek, J., Budtz, H.C., Kermanizadeh, A., Banerjee, A., Ercal, N., Vogel, U., Wallin, H. and Møller, P. (2015) Acute and Subacute Pulmonary Toxicity and Mortality in Mice after Intratracheal Instillation of $\mathrm{ZnO}$ Nanoparticles in Three Laboratories. Food and Chemical Toxicology, 85, 84-95.

[61] Gao, F., Ma, N.J., Zhou, H., Wang, Q., Zhang, H., Wang, P., Hou, H., Wen, H. and Li L. (2016) Zinc Oxide Nanoparticles Induced Epigenetic Change and G2/M Arrest Are Associated with Apoptosis in Human Epidermal Keratinocytes. International Journal of Nanomedicine, 11, 3859-3874. https://doi.org/10.2147/IJN.S107021 
[62] Shaikh, S.M., Shyama, S.K. and Desai, P.V. (2015) Absorption, LD50 and Effects of $\mathrm{CoO}, \mathrm{MgO}$ and $\mathrm{PbO}$ Nanoparticles on Mice "Mus musculus". IOSR-JESTFT, 9 , 32-38.

[63] Amiri, A., Mohammadi, M. and Shabani, M. (2016) Synthesis and Toxicity Evaluation of Lead Oxide (PbO) Nanoparticles in Rats. Electronic Journal of Biology, 12, 110-114.

[64] Park, E.J. and Park, K. (2009) Oxidative Stress and Pro-Inflammatory Responses Induced by Silica Nanoparticles in Vivo and in Vitro. Toxicology Letters, 184, 1825.

[65] Eom, H.J. and Choi, J. (2009) Oxidative Stress of Silica Nanoparticles in Human Bronchial Epithelial Cell, Beas-2B. Toxicology in Vitro, 23, 1326-1332.

[66] Sergent, J.A., Paget, V. and Chevillard, S. (2012) Toxicity and Genotoxicity of Nano-SiO $\mathrm{S}_{2}$ on Human Epithelial Intestinal HT-29 Cell Line. Annals of Occupational Hygiene, 56, 622-630.

[67] Du, Z.J., Zhao, D.L., Jing, L., Cui, G., Jin, M., Li, Y., Liu, X., Liu, Y., Du, H., Guo, C., Zhou, X. and Sun, Z. (2013) Cardiovascular Toxicity of Different Sizes Amorphous Silica Nanoparticles in Rats after Intratracheal Instillation. Cardiovascular Toxicology, 13, 194-207. https://doi.org/10.1007/s12012-013-9198-y

[68] Petrick, L., Rosenblat, M., Paland, N. and Aviram, M. (2016) Silicon Dioxide Nanoparticles Increase Macrophage Atherogenicity: Stimulation of Cellular Cytotoxicity, Oxidative Stress, and Triglycerides Accumulation. Environmental Toxicology, 31, 713-723. https://doi.org/10.1002/tox.22084

[69] Guo, C., Xia, Y., Niu, P., Jiang, L., Duan, J., Yu, Y., Zhou, X., Li, Y. and Sun, Z. (2015) Silica Nanoparticles Induce Oxidative Stress, Inflammation, and Endothelial Dysfunction in Vitro via Activation of the MAPK/Nrf2 Pathway and Nuclear Factor- $\kappa \mathrm{B}$ Signaling. International Journal of Nanomedicine, 10, 1463-1477. https://doi.org/10.2147/IJN.S76114

[70] Guo, C., Yang, M., Jing, 1., Wang, J., Yu, Y., Li, Y., Duan, J., Zhou, X., Li, Y. and Sun, Z. (2016) Amorphous Silica Nanoparticles Trigger Vascular Endothelial Cell Injury through Apoptosis and Autophagy via Reactive Oxygen Species-Mediated MAPK/Bcl-2 and PI3K/Akt/mTOR Signaling. International Journal of Nanomedicine, 11, 5257-5276. https://doi.org/10.2147/IJN.S112030

[71] Wang, J., Yu, Y., Lu, K., Yang, M., Li, Y., Zhou, X. and Sun, Z. (2017) Silica Nanoparticles Induce Autophagy Dysfunction via Lysosomal Impairment and Inhibition of Autophagosome Degradation in Hepatocytes. International Journal of Nanomedicine, 12, 809-825. https://doi.org/10.2147/IJN.S123596

[72] Katsnelson, B.A., Privalova, L.I., Degtyareva, T.D. Sutunkova, M.P., Minigalieva, I.A., Kireyeva, E.P., Khodos, M.Y., Kozitsina, A.N., Shur, V.Y., Nikolaeva, E.V., Vazhenin, V.A., Potapov, A.P., Morozova, M.V., Valamina, I.E., Tulakina, L.G., Pichugova, S.V. and Beikin, J.B. (2010) Experimental Estimates of the Toxicity of Iron Oxide $\mathrm{Fe}_{3} \mathrm{O}_{4}$ (Magnetite) Nanoparticles. Central European Journal of Occupational and Environmental Medicine, 16, 47-63.

[73] Katsnelson, B.A., Privalova, L.I., Kuzmin, S.V., Degtyareva, T.D., Sutunkova, M.P., Yeremenko, O.S., Minigalieva, I.A., Kireyeva, E.P., Khodos, M.Y., Kozitsina, A.N., Malakhova, N.A., Glazyrina, J.A., Shur, V.Y., Shishkin, E.I. and Nikolaeva, E.V. (2010) Some Peculiarities of Pulmonary Clearance Mechanisms in Rats after Intratracheal Instillation of Magnetite $\left(\mathrm{Fe}_{3} \mathrm{O}_{4}\right)$ Suspensions with Different Particle Sizes in the Nanometer and Micrometer Ranges: Are We Defenseless against Nanoparticles? International Journal of Occupational and Environmental Health, 16, 508524. 
[74] Katsnelson, B.A., Degtyareva, T.D., Minigalieva, I.A., Privalova, L.I., Kuzmin, S.V., Yeremenko, O.S., Kireyeva, E.P., Sutunkova, M.P., Valamina, I.I., Khodos, M.Y., Kozitsina, A.N., Shur, V.Y., Vazhenin, V.A., Potapov, A.P. and Morozova, M.V. (2011) Subchronic Systemic Toxicity and Bio-Accumulation of $\mathrm{Fe}_{3} \mathrm{O}_{4}$ Nano- and Microparticles Following Repeated Intraperitoneal Administration to Rats. International Journal of Toxicology, 30, 60-67. https://doi.org/10.1177/1091581810385149

[75] Katsnelson, B.A., Privalova, L.I., Kuzmin, S.V., Gurvich, V.B., Sutunkova, M.P., Kireyeva, E.P. and Minigalieva I.A. (2012) An Approach to Tentative Reference Levels Setting for Nanoparticles in the Workroom Air Based on Comparing Their Toxicity with That of Their Micrometric Counterparts: A Case Study of Iron Oxide $\mathrm{Fe}_{3} \mathrm{O}_{4}$. ISRN Nanotechnology, 2012, Article: ID 143613.

https://doi.org/10.5402/2012/143613

[76] Katsnelson, B.A., Privalova, L.I., Sutunkova, M.P., Khodos, M.Y., Shur, V.Y., Shishkina, E.V., Tulakina, L.G., Pichugova, S.V. and Beikin, J.B. (2012) Uptake of Some Metallic Nanoparticles by, and Their Impact on Pulmonary Macrophages in Vivo as Viewed by Optical, Atomic Force, and Transmission Electron Microscopy. Journal of Nanomedicine \& Nanotechnology, 3, 129.

[77] Katsnelson, B.A., Privalova, L.I., Sutunkova, M.P., Tulakina, L.G., Pichugova, S.V., Beykin, J.B. and Khodos, M.J. (2012) Interaction of Iron Oxide $\mathrm{Fe}_{3} \mathrm{O}_{4}$ Nanoparticles and Alveolar Macrophages in Vivo. Bulletin of Experimental Biology and Medicine, 152, 627-629. https://doi.org/10.1007/s10517-012-1593-Z

[78] Katsnelson, B.A., Privalova, L.I., Gurvich, V.B., Makeyev, O.H., Shur, V.Ya., Beikin, Ya.B., Sutunkova, M.P., Kireyeva, E.P., Minigalieva, I.A., Loginova, N.V., Vasilyeva, M.S., Korotkov, A.V., Shuman, E.A., Vlasova, L.A., Shishkina, E.V., Tyurnina, A.E., Kozin, R.V., Valamina, I.E., Pichugova, S.V. and Tulakina, L.G. (2013) Comparative in Vivo Assessment of Some Adverse Bio-Effects of Equidimensional Gold and Silver Nanoparticles and the Attenuation of Nanosilver's Effects with a Complex of Innocuous Bioprotectors. International Journal of Molecular Sciences, 14, 24492483. https://doi.org/10.3390/ijms14022449

[79] Katsnelson, B.A., Minigalieva, I.A., Privalova, L.I., Sutunkova, M.P., Gurvich, V.B., Shur, V.Ya., Shishkina, E.V., Varaksin, A.N. and Panov, V.G. (2014) Lower Airways Response in Rats to a Single or Combined Intratracheal Instillation of Manganese and Nickel Nanoparticles and Its Attenuation with a Bio-Protective Pre-Treatment. Toxicological Review, 129, 8-14.

[80] Katsnelson, B.A., Privalova, L.I., Gurvich, V.B., Kuzmin, S.V., Kireyeva, E.P., Minigalieva, I.A., Sutunkova, M.P., Loginova, N.V., Malykh, O.L., Yarushin, S.V., Soloboyeva, J.I. and Kochneva N.I. (2014) Enhancing Population's Resistance to Toxic Exposures as an Auxilliary Tool of Decreasing Environmental and Occupational Health Risks (a Self-Overview). Journal of Environmental Protection, 5, 1435-1449. https://doi.org/10.4236/jep.2014.514137

[81] Privalova, L.I., Katsnelson, B.A., Loginova, N.V., Gurvich, V.B., Shur, V.Y., Beikin, Y.B., Sutunkova, M.P., Minigalieva, I.A., Shishkina, E.V., Pichugova, S.V., Tulakina, L.G. and Beljayeva, S.V. (2014) Some Characteristics of Free Cell Population in the Airways of Rats after Intratracheal Instillation of Copper-Containing Nano-Scale Particles. International Journal of Molecular Sciences, 15, 21538-21553. https://doi.org/10.3390/ijms151121538

[82] Privalova, L.I., Katsnelson, B.A., Loginova, N.V., Gurvich, V.B., Shur, V.Y., Valamina, I.E., Makeyev, O.H., Sutunkova, M.P., Minigalieva, I.A., Kireyeva, E.P., Rusakov, V.O., Tyurnina, A.E., Kozin, R.V., Meshtcheryakova, E.Y., Korotkov, A.V., Shuman, E.A., Zvereva, A.E. and Kostykova S.V. (2014) Subchronic Toxicity of Copper Oxide Nanoparticles and Its Attenuation with the Help of a Combination of 
Bioprotectors. International Journal of Molecular Sciences, 15, 12379-12406. https://doi.org/10.3390/ijms150712379

[83] Minigalieva, I.A., Katsnelson, B.A., Privalova, L.I., Sutunkova, M.P., Gurvich, V.B., Shur, V.Y., Shishkina, E.V., Valamina, I.E., Makeyev, O.H., Panov, V.G., Varaksin, A.N., Grigoryeva, E.V. and Meshtcheryakova, E.Y. (2015) Attenuation of Combined Nickel (II) Oxide and Manganese (II,III) Oxide Nanoparticles' Adverse Effects with a Complex of Bioprotectors. International Journal of Molecular Sciences, 16, 2255522583. https://doi.org/10.3390/ijms160922555

[84] Katsnelson, B.A., Privalova, L.I., Sutunkova, M.P., Privalova, L.I., Varaksin, A.N., Gurvich, V.B., Sutunkova, M.P., Shur, V.Y., Shishkina, E.V., Valamina, I.E. and Makeyev, O.H. (2015) Some Patterns of Metallic Nanoparticles' Combined Subchronic Toxicity as Exemplified by a Combination of Nickel and Manganese Oxide Nanoparticles. Food and Chemical Toxicology, 86, 351-364.

[85] Katsnelson, B.A., Panov, V.G., Minigaliyeva, I.A., Varaksin, A.N., Privalova, L.I., Slyshkina, T.V. and Grebenkina, S.V. (2015) Further Development of the Theory and Mathematical Description of Combined Toxicity: An Approach to Classifying Types of Action of Three-Factorial Combinations (a Case Study of ManganeseChromium-Nickel Subchronic Intoxication). Toxicology, 334, 33-44. https://doi.org/10.1016/j.tox.2015.05.005

[86] Katsnelson, B.A., Privalova, L.I., Sutunkova, M.P., Minigalieva, I.A., Gurvich, V.B., Shur, V.Y., Makeyev, O.H., Valamina, I.E. and Grigoryeva, E.V. (2015) Is It Possible to Enhance the Organism's Resistance to Toxic Effects of Metallic Nanoparticles? Toxicology, 337, 79-82. https://doi.org/10.1016/j.tox.2015.09.001

[87] Sutunkova, M.P., Katsnelson, B.A., Privalova, L.I., Gurvich, V.B., Konysheva, L.K., Shur, V.Y., Shishkina, E.V., Minigalieva, I.A., Solovjeva, S.N., Grebenkina, S.V. and Zubarev, I.V. (2016) On the Contribution of the Phagocytosis and the Solubilization to the Iron Oxide Nanoparticles Retention in and Elimination from Lungs under Long-Term Inhalation Exposure. Toxicology, 363-364, 19-28. https://doi.org/10.1016/j.tox.2016.07.006

[88] CDC and NIOSH (2011) Current Intelligence Bulletin 63: Occupational Exposure to Titanium Dioxide. US Department of Health and Human Services, NIOSH, Cincinnati.

[89] Safe Work Australia (2010) Hazardous Substances Information System (HSIS).

[90] Katsnelson, B.A., Privalova, L.I., Kuzmin, S.V., Degtyareva, T.D. and Soloboyeva, J.I. (2008) "Biological Prophylaxis"-One of the Ways to Proceed from the Analytical Environmental Epidemiology to the Population Health Protection. Central European Journal of Occupational and Environmental Medicine, 14, 41-42.

[91] Minigalieva, I.A., Katsnelson, B.A., Panov, V.G., Privalova, L.I., Varaksin, A.N., Gurvich, V.B., Sutunkova, M.P., Shur, V.Ya., Shishkina, E.V., Valamina, I.E., Makeyev, O.H. and Klinova, S.V. (2017) In Vivo Toxicity of Copper Oxide, Lead Oxide and Zinc Oxide Nanoparticles Acting in Different Combinations and Its Attenuation with a Complex of Innocuous Bio-Protectors. Toxicology, 380, 72-93. https://doi.org/10.1016/j.tox.2017.02.007

[92] Morosova, K.I., Aronova, G.V., Katsnelson, B.A., Velichkovski, B.T., Genkin, A.M., Elnichnykh, L.N. and Privalova, L.I. (1982) On the Defensive Action of Glutamate on the Cytotoxicity and Fibrogenicity of Quartz Dust. Occupational and Environmental Medicine, 39, 244-252. https://doi.org/10.1136/oem.39.3.244

[93] Fröhlich, E. (2013) Cellular Targets and Mechanisms in the Cytotoxic Action of Non-Biodegradable Engineered Nanoparticles. Current Drug Metabolism, 14, 976988. https://doi.org/10.2174/1389200211314090004 
[94] Karki, P., Webb, A., Smith, K., Lee, K., Son, D.S., Aschner, M. and Lee, E. (2013) cREB and NF-kappaB Mediate the Tamoxifen-Induced Upregulation of GLT-1 in Rat Astrocytes. Journal of Biological Chemistry, 288, 28975-28986. https://doi.org/10.1074/jbc.M113.483826

[95] White, L.D., Cory-Slechta, D.A., Gilbert, M.E., Tiffany-Castiglioni, E., Zawia, N.H., Virgolini, M., Rossi-George, A., Lasley, S.M., Qian, Y.C. and Basha, M.R. (2007) New and Evolving Concepts in the Neurotoxicology of Lead. Toxicology and Applied Pharmacology, 225, 1-27.

[96] Desole, M.S., Esposito, G., Migheli, R., Sircana, S., Delogu, M.R., Fresu, L., Miele, M., de Natale, G. and Miele, E. (1997) Glutathione Deficiency Potentiates Manganese Toxicity in Rat Striatum and Brainstem and in PC12 Cells. Pharmacological Research, 36, 285-292.

[97] Katsnelson, B.A., Konysheva, L.K., Privalova, L.Y. and Sharapova, N.Y. (1997) Quartz Dust Retention in Rat Lungs under Chronic Exposure Simulated by a Multicompartmental Model: Further Evidence of the Key Role of the Cytotoxicity of Quartz Particles. Inhalation Toxicology, 9, 703-715.

https://doi.org/10.1080/089583797197953

\section{Submit or recommend next manuscript to SCIRP and we will provide best} service for you:

Accepting pre-submission inquiries through Email, Facebook, LinkedIn, Twitter, etc. A wide selection of journals (inclusive of 9 subjects, more than 200 journals)

Providing 24-hour high-quality service

User-friendly online submission system

Fair and swift peer-review system

Efficient typesetting and proofreading procedure

Display of the result of downloads and visits, as well as the number of cited articles

Maximum dissemination of your research work

Submit your manuscript at: http://papersubmission.scirp.org/

Or contact jep@scirp.org 